\title{
Synthesis of protease inhibitors derivatives
}

\section{Juliano Bosenbecker, Adriana M. das Neves, Daniela P. Gouvêa, Maieli C. Soares, Wilson Cunico*}

Núcleo de Química Aplicada (NuQuia), Departamento de Química Orgânica, UFPel, Pelotas, RS, Brazil

*wjcunico@yahoo.com.br

Keywords: protease inhibitor, malaria, hydroxyethylamine.

\section{INTRODUCTION}

Malaria accounts for more than a million deaths each year, Plasmodium falciparum is the most dangerous form of the four malarial parasites that infect humans. A particular family of aspartic proteases, known as the plasmepsins, appears to be involved in the initial steps of the degradation of hemoglobin which provides nutrients for its growth and maturation of parasite. This degradation of hemoglobin is one of the critical stages of the life cycle of the Plasmodium during human infection, so it was an attractive antimalarial drug target. A secondary alcohol is usually the structural element of choice to inhibit aspartic protease. This element mimics the tetrahedral intermediate during peptide bond cleavage by aspartic proteases. Recently, we published the antimalarial (Figure 1) ${ }^{1}$ and tuberculostatic ${ }^{2}$ activities of protease hydroxyethylamine-based inhibitors. In this work, we report the synthesis of novel protease inhibitors derivatives that have potential antimalarial activity.

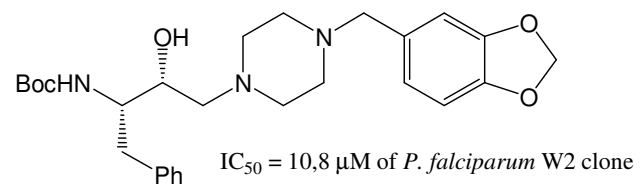

Figure 1. Structure of hydroxyethylamine with antimalarial activity. ${ }^{1}$

\section{RESULTS AND DISCUSSION}

The study of conditions for the formation of compounds 5,6a-d and $\mathbf{7}$ is summarized in Scheme 1 and Table 1. The protease inhibitors were prepared by selective ring-opening of the (2S,3S)Boc-phenylalanine epoxide 1 with aminoethylazines 2a-d, hydroxyethylazines 3a-d and aminopropylmorfoline 4, respectively, refluxing isopropanol (IPA) for 16 hours. The desired products were obtained in high yields after the purification (82-90\%). The structures of compounds 5,6a-d and 7 were confirmed and characterized by ${ }^{1} \mathrm{H}$ and ${ }^{13} \mathrm{C}$ NMR.

\section{Scheme 1}

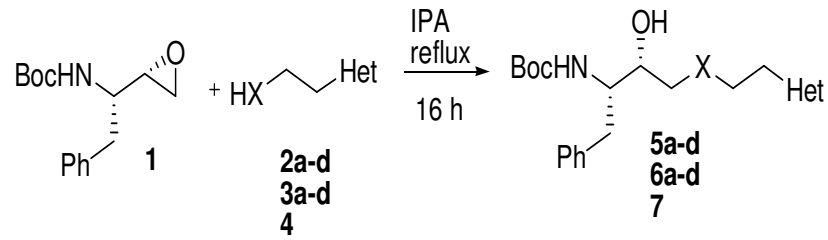

Table 1. Yields of compounds 5,6a-d and 7

\begin{tabular}{|c|c|c|c|}
\hline Product & $X$ & Het & Yield (\%) \\
\hline $5 a$ & $\mathrm{NH}$ & & 82 \\
\hline $5 b$ & $\mathrm{NH}$ & & 86 \\
\hline $5 c$ & $\mathrm{NH}$ & & 83 \\
\hline $5 d$ & $\mathrm{NH}$ & & 87 \\
\hline $6 a$ & 0 & & 88 \\
\hline $6 b$ & O & & 85 \\
\hline $6 c$ & $\mathrm{O}$ & & 89 \\
\hline $6 d$ & $\mathrm{O}$ & & 85 \\
\hline 7 & $\mathrm{NHCH}_{2}$ & & 90 \\
\hline
\end{tabular}

\section{CONCLUSION}

The protease inhibitors derivatives 5,6a-d and 7 could be synthesized in good yields. The study of these compounds as antimalarial agents is ongoing.

\section{ACKNOWLEDGEMENTS}

UFPEL, Farmanguinhos, CNPq, CAPES.

\section{REFERENCES}

${ }^{1}$ Cunico,W.;Gomes,R.B.C.; Moreth, M.; Manhanini, P.D.; Figueiredo, H. I.; Penido, C.; Henriques, G.M.O.M.; Varotti, P.F.; Krettli, U.A.; Eurp. J. Med. Chem.,2009,44,1363.

${ }^{2}$ Cunico, W.; Gomes,.R.B.C.; Ferreira, L.G.M.; Ferreira, T.G.; Cardinot; D.

Souza, M.V.N.;Lourenço, M.C.S., Eurp. J. Med. Chem., 2011, 46, 974. 